\title{
Assessing the hydrogen peroxide effect along with sodium hypochlorite against marine blue mussels aimed at antifouling usage
}

\author{
Md. Niamul Haque ${ }^{1}$, Sunghyun Kwon ${ }^{2^{+}}$ \\ ${ }^{1}$ Department of Ocean System Engineering, College of Marine Science, Gyeongsang National University, Cheondaegukchi-Gil 38, Tongyeong 53064, \\ Republic of Korea \\ ${ }^{2}$ Department of Marine Environmental Engineering, College of Marine Science, Engineering Research Institute (ERI), Gyeongsang National University, \\ Cheondaegukchi-Gil 38, Tongyeong 53064, Republic of Korea
}

\begin{abstract}
Chlorination has been the most common antifouling method, but alternatives are under searching. In this article, we report how the hydrogen peroxide could enhance the effect of chlorination to prevent fouling by inhibiting larvae settlement and abatement of mussel colonization or by extinct of them; through marine mussel Mytilus edulis. The addition of hydrogen peroxide shows synergic effect on the veliger larvae (up to 19 folds) and effectively reduces required time of mussel mortality by $8-22 \%$. For resolution of micro- and macro-fouling caused by the marine mussel, as well as diminishing of time and conventional chlorine dose could be important factor in favour of environment and economics.
\end{abstract}

Keywords: Biofouling, Hydrogen peroxide, Mytilus edulis, Sodium hypochlorite, Veliger larvae

\section{Introduction}

Micro- and macro-fouling can be a potentially serious problem in a submerged cooling system, leading to the reduced heat exchange efficiency [1], to the reduced water flow [2] and to the blockage of small condenser tubes [3]. There have been reports on mussel abatement strategies for a couple of local facilities like Perry Nuclear Power plants, Ontario Hydro facilities and Detroit Edison facilities [3-5]. Some methods have been employed with success in Netherlands, including chemical addition, heat treatment, drying, surface coatings, water velocity, and micro sieves [6-7].

In order to minimize this undesirable phenomenon and its effects, antifouling treatments are applied to reduce the deposits accumulation. Usually a chemical control is applied based on the addition of biocides to kill microorganisms in cooling water, or at least to reduce their activity. A wide range of chemicals are used as biocide agents. They can be classified as oxidants (chlorine and other chlorine products, hydrogen peroxide, ozone) and nonoxidizing agents (amines, heavy metals, aldehydes, organo-bromine compounds) [8]. Chlorination has been the most commonly used to control fouling. However, owing to increasing concern about toxicity of chlorine and its intermediates to aquatic life, several countries are making effort to minimize chlorine residuals in the discharges [9]. The presence of the added toxic chemicals in the discharge amplifies the environmental hazards [10].

Mussels and mussel final larvae (plantigrade) have the ability to select the surface actively by exposing their foot and crawling and attachment is made by the production of byssal threads [11]. A basal adhesion disk was recently described in pre-ancestral stages constituted by elongated and interlocked fibrous cells, which seem to provide mechanical support during permanent settlement [12]. The collagen gland produces byssal collagen core, the accessory gland is responsible for the proteinaceous cortex, phenol glands produce the proteinaceous adhesive and other glandular system is known to produce a sulfur-rich mucopolysaccharide [13]. Byssal thread differentiated structure is primarily attributed
This is an Open Access article distributed under the terms of the Creative Commons Attribution Non-Commercial License (http://creativecommons.org/licenses/by-nc/3.0/) which permits unrestricted non-commercial use, distribution, and reproduction in any medium, provided the original work is properly cited.
Received March 14, 2016 Accepted November 3, 2016

${ }^{\dagger}$ Corresponding author

Email: shkwon@gnu.ac.kr

Tel: +82-55-772-9132 Fax: +82-55-772-9139

Copyright (C) 2017 Korean Society of Environmental Engineers 
to the occurrence of different collagenous proteins known as PreCol variants, with both adhesive and cohesive properties that ensure byssus mechanical properties as shock absorber [14]. Foot proteins were also found in the constitution of the adhesive plaque and threads as both protective cuticular proteins, matrix proteins and also adhesive proteins [15-16]. In addition, protein family generically denominated Mytilus. Similar proteins were also identified in other mussel species as Dreissena polymorpha [17]. Since $M$. edulis has a life phase-dependent tolerance to toxicants, increasing with age, this study gives an emphasis on the embryonic level, which is the most vulnerable phase in their life cycle [18].

An additional point is that the chemical residues in the aquatic environment are found as mixtures, i.e. organisms are exposed to more than one single anthropogenic ally-derived stressor. The combined effects of such mixtures can be more toxic to organisms than single compounds [19]. For example, in Daphnia, a mixture of diclofenac sodium and Ibuprofen was more toxic than single compounds [20] and clofibric acid with Fluoxetine caused significant mortality in this species at $100 \mu \mathrm{g} / \mathrm{L}$ while at $10 \mu \mathrm{g} / \mathrm{L}$ it resulted in malformed morphology [21]. Thus, an accurate determination of the toxicity of mixtures of compounds is essential in any realistic assessment.

In our work, we employed hydrogen peroxide and sodium hypochlorite as a combinatory antifoulant, being supposed to produce active hydroxyl free radicals, and hypochlorous acid/hypochlorite ions in sea water, respectively. This formulation of treatment may enhance the sodium hypochlorite efficiency to result in a minimal dosage and shortening exposure time. To test this hypothesis, mussel larva of $M$. edulis and its two groups of adult mussels (classified as size) were tested. Larva settlement inhibition/mortality and adult mussel mortality were measured in counts at various concentration of residual chlorine with hydrogen peroxide.

\section{Materials and Methods}

\subsection{Larvae Assembling and Preservation}

Veliger larvae were supplied by Marine Fisheries Resources Research Institute, Tongyeong, South Korea. The veliger larvae have been preserved in a $10 \mathrm{~L}$ glass jar with filtered sea water. The preservation jars was conveyed to the institute laboratory with minimum hassle to prevent any harm as well as death. The $\mathrm{pH}$, temperature, and salinity of the water were $7.7,20.1^{\circ} \mathrm{C}$, $33 \%_{0}$, respectively, and were properly maintained with caution in entire experiment.

\subsection{Mortality Test of Larvae}

Stock solution (1,000 mg/L) of $\mathrm{H}_{2} \mathrm{O}_{2}$ and sodium hypochlorite ( $\mathrm{NaOCl}$ ) were prepared from $\mathrm{H}_{2} \mathrm{O}_{2}$ (30\%; Merk, Germany), NaOCl (8\%; Junsei Chemicals Co. Ltd., Japan) analytical grade solution using distilled water in a $1 \mathrm{~L}$ volumetric flask. $0.05 \mathrm{mg} / \mathrm{L}, 0.1$ $\mathrm{mg} / \mathrm{L}, 0.3 \mathrm{mg} / \mathrm{L}, 0.5 \mathrm{mg} / \mathrm{L}$ and $0.7 \mathrm{mg} / \mathrm{L}$ free residual $\mathrm{NaOCl}$ solutions were prepared in $2 \mathrm{~L}$ glass beakers with sea water from stock solution. Sea water were used because of the targeted application of this study mostly is in sea water environment. Consecutively these solutions were set at $0.5 \mathrm{mg} / \mathrm{L}$ concentration of $\mathrm{H}_{2} \mathrm{O}_{2}$ by adding stock solution and were set as combined mixture. An aliquot of $100 \mu \mathrm{L}$ larvae aliquot was placed in each beaker using a micropipette. Ten minute duration was allowed for each run before counting

\subsection{Veliger Larvae Counting}

Several volumes ( $500 \mu \mathrm{L}, 300 \mu \mathrm{L}, 200 \mu \mathrm{L}, 100 \mu \mathrm{L}$ ) of veliger aliquot were checked for estimating the measurable amount of veliger larvae. $100 \mu \mathrm{L}$ volume of veliger aliquot was selected for test (around 200-500 veliger content) and was placed in each $2 \mathrm{~L}$ glass beaker (combined mixture) using a micropipette. Ten minute contact was allowed for each run before calculating live and dead veliger. The target veliger larvae were filtered by $40 \mu \mathrm{m}$ sieve and were transferred to the Sedgwick Rafter counting cell for counting. The mortality of veliger was judged by the presence or absence of ciliary movement, either inside the translucent shell or on an extended velum [22]. Counts were made with a microscope (Olympus BX40, Olympus America Inc., USA) with x200 magnification and in triplicate. Tests were conducted two times.

\subsection{Mussel Collection and Preservation}

Mussels for the experiments were collected from Jinhae-gu, located in Changwon-si of South Korea (350.'39.5"N and $\left.128^{\circ} 44^{\prime} 19.8^{\prime \prime} \mathrm{E}\right)$. The collected mussels were as attached with growing rope and were preserved in a seawater flowing glass aquarium. Mussels were gently removed from the rope by cutting their byssus threads using a pair of scissors and were immediately transferred to an ice box. The ice box had conveyed in laboratory within minimum time and minimum hassle. Mussels acclimated for at least 48 $\mathrm{h}$ in the laboratory and were used for each experiment.

\subsection{Oxidant Toxicity on Mussel}

The experiments were conducted in a continuous static chlorination system, following the procedure outlined by Rajagopal et al. [23]. Seawater was stored in a $150 \mathrm{~L}$ aquarium tank. One set of glass beaker containing $0.05,0.1,0.5,1,2,4 \mathrm{mg} / \mathrm{L}$ of free residual chlorine solution were prepared from the stock solution. The input dosage of chlorine were higher that have optimized before starting test. The elements of the natural sea water such as ammonia, $\mathrm{Fe}^{+2}, \mathrm{H}_{2} \mathrm{~S}$, etc. may be the cause of this occurrences. Another set of glass beaker were thoroughly mixed with required volume of stock solution to make it $2 \mathrm{mg} / \mathrm{L}$ hydrogen peroxide $\left(\mathrm{H}_{2} \mathrm{O}_{2}\right)$. After $2 \mathrm{~d}$ of acclimation, 20 mussel of $14 \mathrm{~mm}$ size and another 20 mussel of $25 \mathrm{~mm}$ size were randomly picked and then introduced into the experimental glass beaker of known free residual chlorine concentrations and peroxide oxidant solutions. The levels of the free residual chlorine and peroxide were monitored at $3 \mathrm{~h}$ intervals and adjusted (if need). So, the rate of concentration declining data was not point out. The chlorine measurement was carried out using DPD (N, N-diethyl-p-phenylenediamine) pocket colorimeter (HACK, China) [24] and peroxide measurement was carried out by HACK Hydrogen Peroxide Test Kit [22]. Mortality was assessed at 6 hour intervals. The criterion for mortality of mussels was a shell valve gape with no response of exposed mantle tissue to external stimuli [25]. Dead mussels were immediately removed 
from the tank. The number of dead mussels in each checking was recorded. The same experiment was repeated three times for each size group. Total number of used mussel for chlorine only and combined chlorine concentration tests were $(14 \mathrm{~mm}$ and $25 \mathrm{~mm}$ (20 mussels in each experiment) $\times 7$ chlorine concentration (including control) $\times 2$ size groups $\times 3$ replicates $=840$ mussels $\times 2$ set $=1,680$ ).

\subsection{Statistical Analysis}

Cumulative mortality versus time plots are analyzed by method based on cumulative normal distribution (e.g. probit analysis). Aside from simplicity, an advantage of this method over methods such as probit analysis is that 0 and $100 \%$ mortality data can be used in the fitting procedure as no transformation of raw data are required [26]. The differences in mussel mortality time between $14 \mathrm{~mm}$ and $25 \mathrm{~mm}$ size were compared by student t-test after Bonferroni correction [27]. The data obtained on mortality of mussel at different chlorine doses were subjected to probit analysis, yielding the statistic $\mathrm{LT}_{50}$. The analyses were performed using standard spreadsheet (Microsoft EXCEL) and Sigma plot 10.

\section{Results and Discussion}

Fig. 1 depicted the behavior of D-shaped veliger larvae at the present research. Short-term treatments on veliger larvae of $M$. edulis with oxidants resulted in veliger mortality. This was true for all free residual chlorine concentrations combined with 0.5 mg/L hydrogen peroxide. Fig. 2 demonstrates the 10 min contact mortality for the studied oxidant set. When sodium hypochlorite ( $\mathrm{NaOCl}$ ) added to water, it almost instantaneously forms hypochlorous acid (HOCl). Sole dose of $0.5 \mathrm{mg} / \mathrm{L}$ hydrogen peroxide showed $17 \%$ larvae mortality. Larvae mortality for only free residual chlorine was increased with increasing free residual chlorine concentrations. The lowest dose of free residual chlorine of 0.05 $\mathrm{mg} / \mathrm{L}$ was not achieved larvae mortality, while the veliger larvae mortality was $3 \%$ for $0.1 \mathrm{mg} / \mathrm{L}, 8 \%$ for $0.3 \mathrm{mg} / \mathrm{L}, 12 \%$ for 0.5 $\mathrm{mg} / \mathrm{L}, 16 \%$ for $0.7 \mathrm{mg} / \mathrm{L}$ free residual chlorine. This indicates that the veliger larvae of $M$. edulis thus could not be completely settled or inactivated with the stated hypochlorite doses.

To achieve the free residual chlorine concentration higher dosage were needed. So it is clear that the sea water contents various elements that are the cause of extra consumption of chlorine. We assume that ammonia and other elements of sea water (including trace amount of $\mathrm{Fe} / \mathrm{Fe}^{+2}, \mathrm{H}_{2} \mathrm{~S}$, etc.) react with dissociate sodium hypochlorite and generate byproducts like hydroxyl amine in presence of $\mathrm{H}_{2} \mathrm{O}_{2}$, chloramine, nitrogen trichloride, etc. that might be produce hydroxyl free radical from hydrogen peroxide. The production of ${ }^{\circ} \mathrm{OH}$ increased with increasing concentration of either hydroxyl amine or hydrogen peroxide as well as decreasing $\mathrm{pH}$. Considering hydroxyl amine has similar reducing activity and the ionizable hydroxyl group, it is hypothesized that hydroxyl amine may active $\mathrm{H}_{2} \mathrm{O}_{2}$ to form ${ }^{\circ} \mathrm{OH}$ without a transition metal was reported by Liwei et al. [28] and Tomat et al. [29]. Free ${ }^{\circ} \mathrm{OH}$ radicals penetrate cells, causing site-directed damage especially of DNA due to metal-dependent ${ }^{\circ} \mathrm{OH}$ formation [30].

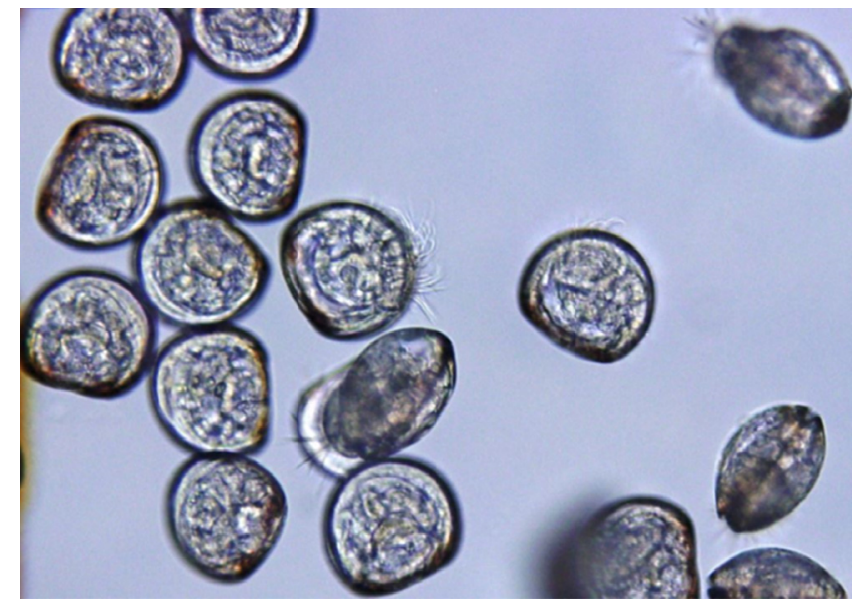

Fig. 1. D-shaped valiger larvae (x200 magnification) of this study. Larvae settlement prevention is one of the early applicable strategies of anti-microfouling.

Comparing mortality of mussels' larvae for three methods

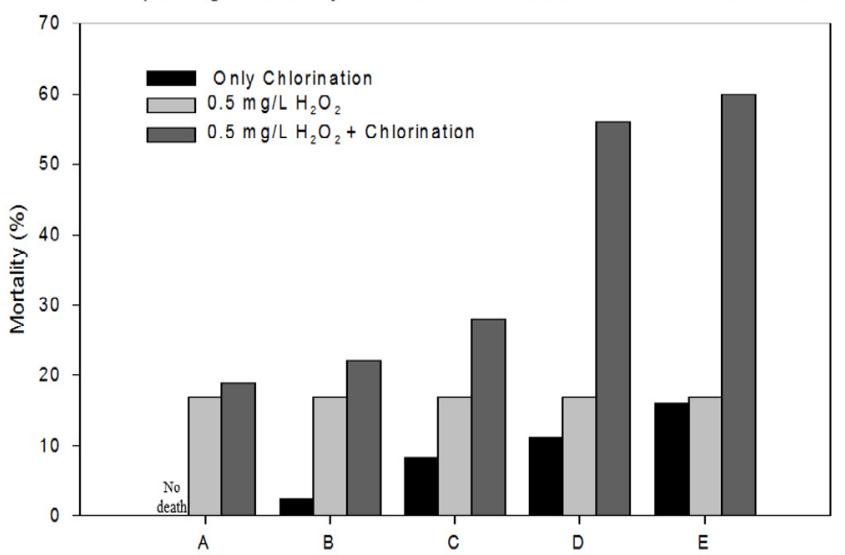

Fig. 2. Mortality comparison of veliger larvae due to different oxidant exposure. A, B, C, D, and E indicate the concentrations of $0.05,0.1$, $0.3,0.5,0.7 \mathrm{mg} / \mathrm{L}$ free residual chlorine respectively and $0.5 \mathrm{mg} / \mathrm{L}$ $\mathrm{H}_{2} \mathrm{O}_{2}$ conjointly.

Veliger larvae are believed to have their intrinsic defensive system against foreign toxic substances [31]. With the increase of oxygen in the surrounding environment, the single electrons react promiscuously with oxygen leading to the formation of superoxide radical $\left(\mathrm{O}^{\mathbf{2}}\right)$ that can be converted in other reactive oxygen species such as hydroxyl radical $\left({ }^{\circ} \mathrm{OH}\right)$ [32]. Parallel to the innovation of using oxygen for energy production, animals have evolved some sophisticated and multifaceted antioxidant defense systems to avoid or minimize the inevitable production of reactive oxygen species [33]. These antioxidants are distributed within the cytoplasm and among various organelles and work in a series of integrated reactions to convert reactive oxygen species to more stable molecules eventually oxygen or water. However, the antioxidant machinery is not $100 \%$ efficient in mopping up reactive oxygen species and some radicals always evade the protection system. However, when the balance between pro and antioxidants is disrupted, 
reactive oxygen species escape the antioxidant capacities in a greater extend, and oxidative stress occurs. According to this theory, the reason why animals ultimately die is because of the accumulated damage that these oxygen free radicals and their derivatives cause. In the light of this theory, animals with low antioxidant capacities or higher rates of reactive oxygen species production are expected to accumulate damage at a faster rate and live a comparatively shorter life.

Chemical toxicity will be effective only after they are crossing or breaking that system. We assume that $0.05 \mathrm{mg} / \mathrm{L}$ free residual chlorine was not enough to cross the defensive system, which implies the extent of the larvae's toxicity tolerance level. However, in case of the higher oxidant concentrations, the defense system was too fragile to keep them alive as commonly expected in the early developing phase of many other organisms [34]. Although sodium hypochlorite is known to be stronger antifoulant than hydrogen peroxide, the tests indicate that 0.5 $\mathrm{mg} / \mathrm{L}$ hydrogen peroxide, interestingly, achieved higher mortality than $0.5 \mathrm{mg} / \mathrm{L}$ or $0.7 \mathrm{mg} / \mathrm{L}$ sodium hypochlorite: $0.5 \mathrm{mg} / \mathrm{L}$ peroxide showed $20 \%$ higher death rate than $0.5 \mathrm{mg} / \mathrm{L}$ hypochlorite. Recovery of veliger larvae presumably possible because sodium hypochlorite in sea water dissociates over time and at lower initial dosages the concentration soon falls to a level that is less toxic to the larvae [35].

Combined application of $\mathrm{H}_{2} \mathrm{O}_{2} / \mathrm{NaOCl}(0.5 / 0.05,0.5 / 0.1,0.5 / 0.3$, $0.5 / 0.5,0.5 / 0.7 \mathrm{mg} / \mathrm{L}$ ) resulted in the higher larva mortality than single application. Peroxide addition greatly enhanced larvae mortality compared to application of hypochlorite only. Live/death veliger numbers per $100 \mu \mathrm{L}$ volume for various combinations of the two oxidants have shown in Fig. 3. Veliger larvae mortality was shown to be $19 \%$ for $0.5 / 0.05,22 \%$ for $0.5 / 0.1,28 \%$ for $0.5 / 0.3$, $56 \%$ for $0.5 / 0.5$, $60 \%$ for $0.5 / 0.07 \mathrm{mg} / \mathrm{L}$ in $\mathrm{H}_{2} \mathrm{O}_{2} / \mathrm{NaOCl}$ combinations. It should be noted that 3-19 times enhancement in veliger mortality has been achieved by a simple addition of $0.5 \mathrm{mg} / \mathrm{L}$ peroxide, which seems to be a synergic effect on collapsing the larvae's defense system. This attributes that the combined toxicity of the two compounds follows the independent action model. This model assumes dissimilar modes of action of mixture components, which interact with different target molecule (proteins, membrane lipids, DNA, mitochondria, etc.) sites in the exposed organism. As a result, the relative effect of one of the toxicants in a mixture should remain unchanged in the presence of another [36-38] and the overall observed toxicity should be the result of the most active ingredient in the mixture.

Nonetheless, the mortality of larvae is likely to be the larger in the lower larvae population density or to be the smaller in the higher population density, which may imply an affirmative interaction on their defense mechanism in a larger group. However, the mortality may not be required for an oxidant to be $100 \%$. If the presence of oxidant prevents settlement but does not cause higher mortality, the oxidant would be considered successful.

However, such extrapolations are not well evidenced and inter specific differences could also be based on the compound specific mode of action (e.g. for pesticides: [39]. This study highlights the limitations on interspecies correlations of toxicity and the importance of interspecific variability in environmental threat

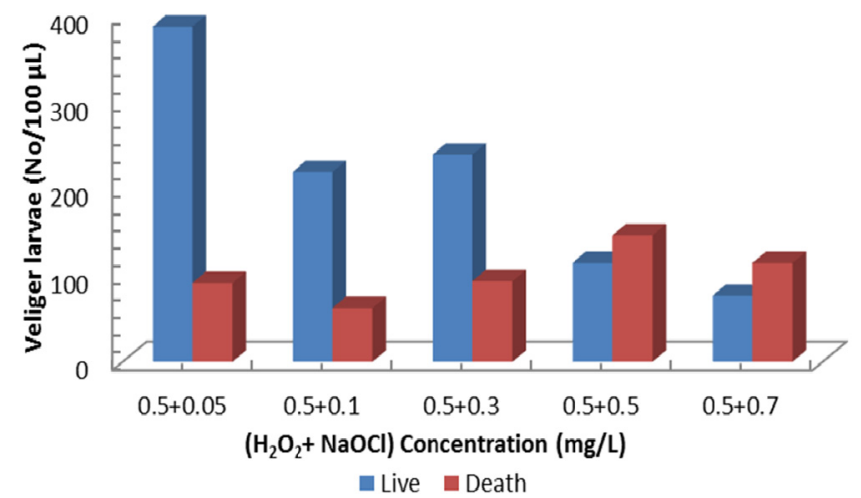

Fig. 3. Veliger larvae density vs $\left(\mathrm{H}_{2} \mathrm{O}_{2} / \mathrm{NaOCl}\right)$ concentration (mg/L). Presence or absence of ciliary movement was the distinction factor of live and death veliger (t-test, $\mathrm{P}<0.01$ ).

assessment. More information is needed about the actual meaning of interspecies relationships [40] based on the differences of bio-uptake and toxic mechanism of action [41] when considering interspecific life histories approach in close phylogenetic species.

The exposure time required for $100 \%$ mortality of all size groups (14 mm and $25 \mathrm{~mm}$ ) of $M$. edulis significantly decreased with increasing free residual chlorine concentration $(\mathrm{P}<0.01)$. For example, mussels in the $14 \mathrm{~mm}$ size group exposed to $0.05 \mathrm{mg} / \mathrm{L}$ free residual chlorine took $702 \mathrm{~h}$ to reach $100 \%$ mortality, whereas those exposed to $4 \mathrm{mg} / \mathrm{L}$ residual chlorine took only $150 \mathrm{~h}$. The two size groups of $M$. edulis were found to have very different time frames to reach $100 \%$ mortality, i.e., difference in an internal resistance to the external toxins for both of $0.05 \mathrm{mg} / \mathrm{L}$ and $4 \mathrm{mg} / \mathrm{L}$ free residual chlorine (P $<0.01$ ). For example, $4 \mathrm{mg} / \mathrm{L}$ free residual chlorine, $14 \mathrm{~mm}$ and $25 \mathrm{~mm}$ mussels took $124 \mathrm{~h}$ and $150 \mathrm{~h}$ respectively, to achieve $100 \%$ mortality. No mortality occurred in control vessel. Rajagopal et al. [42] reported that in D. polymorpha (20 mm), Mytilopsis leucophaeata $(20 \mathrm{~mm})$ and M. edulis $(21$ $\mathrm{mm}$ ), $100 \%$ mortality can be achieved from $588 \mathrm{~h}$ to 1,104 $\mathrm{h}$, at a continuous chlorine concentration of $1 \mathrm{mg} / \mathrm{L}$.

Time required for $100 \%$ mortality of $14 \mathrm{~mm}$ and $25 \mathrm{~mm}$ of $M$. edulis when exposed to combined oxidant $0.05 \mathrm{mg} / \mathrm{L} / 2 \mathrm{mg} / \mathrm{L}$, $0.1 \mathrm{mg} / \mathrm{L} / 2 \mathrm{mg} / \mathrm{L}, 0.5 \mathrm{mg} / \mathrm{L} / 2 \mathrm{mg} / \mathrm{L}, 1 \mathrm{mg} / \mathrm{L} / 2 \mathrm{mg} / \mathrm{L}, 2 \mathrm{mg} / \mathrm{L}$ $/ 2 \mathrm{mg} / \mathrm{L}, 4 \mathrm{mg} / \mathrm{L} / 2 \mathrm{mg} / \mathrm{L}$ in $\mathrm{NaOCl} / \mathrm{H}_{2} \mathrm{O}_{2}$ concentrations are presented in Fig. 4(a) and Fig. 4(b), respectively. As seen in those figures, the rates of mortality development (slopes in graphs) seem to be very alike or similar to each other once mortality initiates. It is very obvious to have a lagging phase, which might be closely related to tolerance of an organism against foreign matter. But after that lagging phase mortality develops at almost same rate until it reaches $100 \%$. In Fig. 4(a), the rates range $0.9 / \mathrm{h}$ to $1.0 / \mathrm{h}$ whereas those range $0.7 / \mathrm{h}$ to $0.8 / \mathrm{h}$ in Fig. $4(\mathrm{~b})$. Those values may characterize the 'size effect' of the blue mussels. That is, the bigger (the older) the mussels become, the lower the rate would be. This seems common in many organisms and predictable (can be also found in lethal dose concept). Hereafter, bivalves possess a high degree of phenotypic plasticity that permits a wide range of responses with respect to growth, age at maturation and record lifespan that are suited to different environ- 

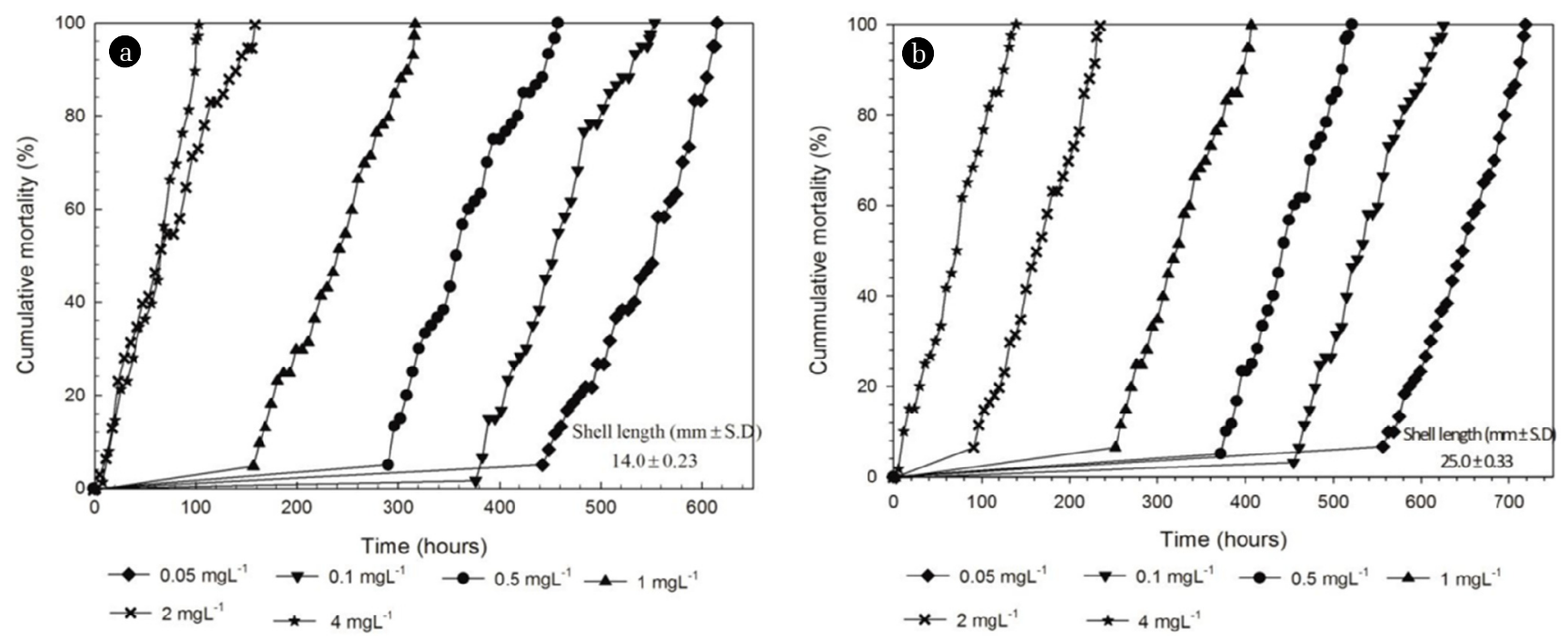

Fig. 4. Cumulative mortality (\%) of $14 \mathrm{~mm}$ size group (a) and $25 \mathrm{~mm}$ size (b) group of blue mussels expose to $0.05 \mathrm{mg} / \mathrm{L} / 2 \mathrm{mg} / \mathrm{L}, 0.1 \mathrm{mg} / \mathrm{L}$ $/ 2 \mathrm{mg} / \mathrm{L}, 0.5 \mathrm{mg} / \mathrm{L} / 2 \mathrm{mg} / \mathrm{L}, 1 \mathrm{mg} / \mathrm{L} / 2 \mathrm{mg} / \mathrm{L}, 2 \mathrm{mg} / \mathrm{L} / 2 \mathrm{mg} / \mathrm{L}, 4 \mathrm{mg} / \mathrm{L} / 2 \mathrm{mg} / \mathrm{L}, \mathrm{NaOCl} / \mathrm{H}_{2} \mathrm{O}_{2}$ concentrations. The criterion for mortality of mussels was shell valve gape with no response of exposed mantle tissues to outer stimuli.

mental conditions [43, 44]. Another implication of this lagging phase is that mussels have an upper threshold for the invading foreign matter in terms of concentration or number of molecules so that they survive until the threshold is crossed over [23].

No mortality occurred in the control tank within experimental duration. The elapsed time for $100 \%$ mortality in $14 \mathrm{~mm}$ and 25 mm mussel groups decreased over ratio of chlorine/peroxide (Fig. 5) and the bigger mussels (25 mm) showed higher resistance than the younger ones $(14 \mathrm{~mm})$. This is probably related to the mode of action of oxidant on the mussel [23, 45]. Under stress, younger might react more rapidly than larger mussel possible due to the variations in the gill area as reported by Jones et al. [46]. Required time for achieving 100\% mortality was reduced with addition

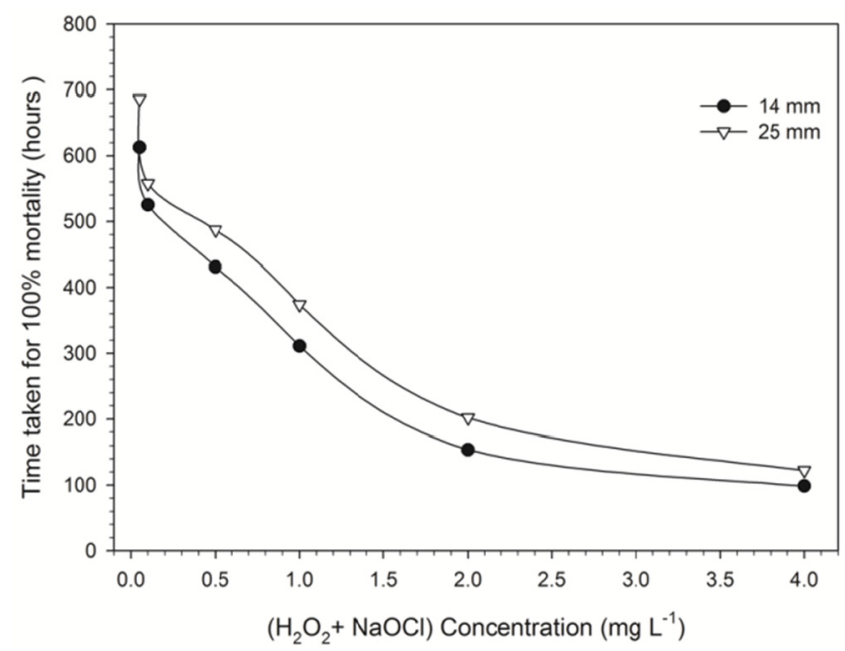

Fig. 5. Required time for $100 \%$ mussel mortality of different size groups of $M$. edulis when exposure to combined $\left(\mathrm{H}_{2} \mathrm{O}_{2} / \mathrm{NaOCl}\right)$ oxidant. The influence of oxidant (mortality) is statistically significant (t-test, $\mathrm{P}<0.01$ ). of $2 \mathrm{mg} / \mathrm{L}$ hydrogen peroxide. Only $2 \mathrm{mg} / \mathrm{L}$ hydrogen peroxide has no mortal effect on both size of blue mussel excluding reducing their moving ability within the same experimental period. The duration of $100 \%$ mortality for the two size groups with different application of oxidants are compared in Fig. 6(a) and Fig. 6(b). Reduction in lethal times was ranged between $8-22 \%$ for 14 mm mussel group and $9-18 \%$ for $25 \mathrm{~mm}$ group with additional application of hydrogen peroxide. The maximum time reduction was $22 \%$ with $2 \mathrm{mg} / \mathrm{L}$ free residual chlorine dose scheduled $14 \mathrm{~mm}$ group whereas it was $18 \%$ with $4 \mathrm{mg} / \mathrm{L}$ free residual chlorine dose when $25 \mathrm{~mm}$ group were subjected to contact compared with chlorination only. For application of sodium hypochlorite along with peroxide usage, it is worthy to note that higher the value of free residual chlorine higher the reduction of lethal time (than only chlorination). Behind of this outcome, probably more active free radical were formed by peroxide and may connect with the synergic impact of applied chemical. This indication is consistent with other studies in the estuarine shrimp Palaemon longirostris [47]. To specify the intrinsic mechanism; obviously it demands more research in directed to the mechanism revelation. In addition the time of mussel mortality has decreased as a pseudo first order kinetics with oxidant concentration.

Fig. 7 (a) is depicted that $-\ln [\mathrm{C}]$ versus time graph fitting (strait line) is pretty good based on $\mathrm{R}^{2}$ value. The time to reach $50 \%$ mortality of $14 \mathrm{~mm}$ and $25 \mathrm{~mm}$ size mussel were investigated by probit and regression analysis (Fig. 7(b)) and also shows a significant dose effect $(\mathrm{P}<0.01)$. The reduction of lethal time might be due to denaturation of cell membranes by high toxicity of oxidant, particularly in the gills [48] but at low toxicity of oxidant are affected only physiological activities such as filtration rate, foot activity index, etc. [23]. The produced results indicate that $M$. edulis is likely to get eliminated at the above combined dosage, as it reaches faster lethality to combination than chlorination alone. However, influence of other factors that may cause 

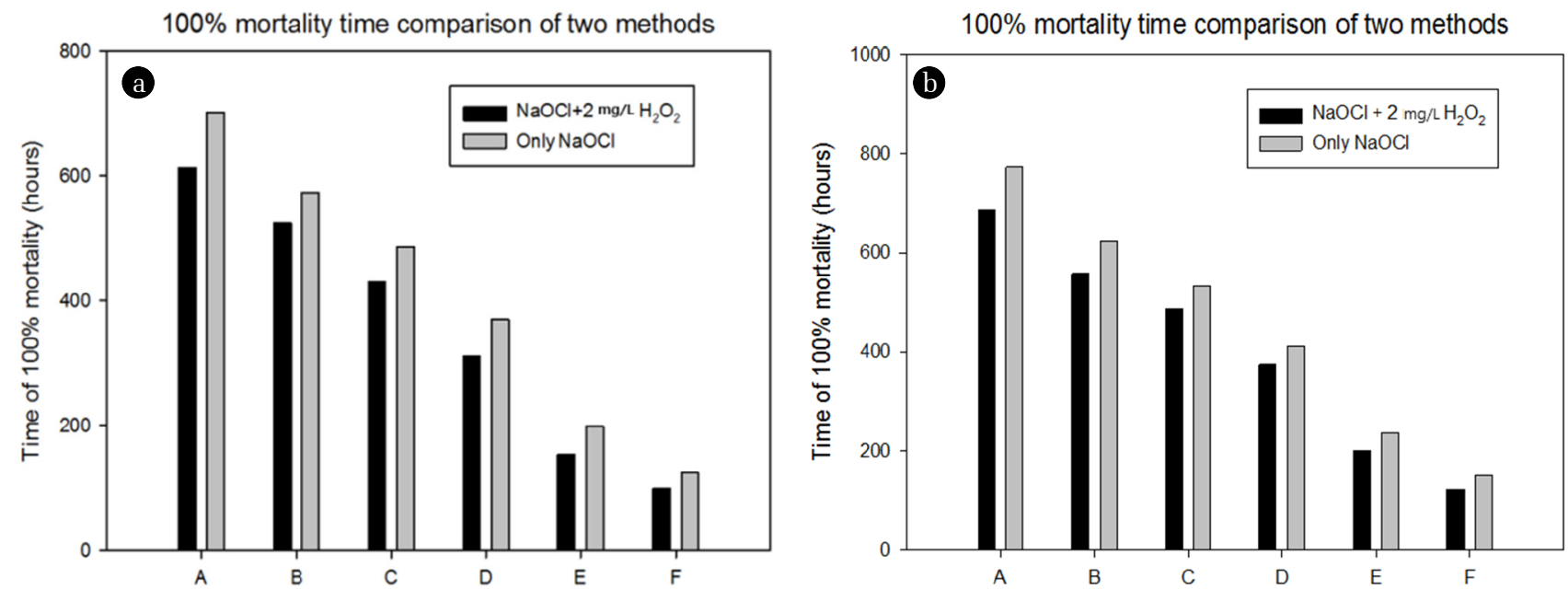

Fig. 6. Required time for $100 \%$ mussel mortality of $14 \mathrm{~mm}$ size group (a) and $25 \mathrm{~mm}$ size groups (b) of $\mathrm{M}$. edulis when exposed to combined oxidant treatment and only chlorination. A, B, C, D, E and F indicate $0.05 \mathrm{mg} / \mathrm{L} / 2 \mathrm{mg} / \mathrm{L}, 0.1 \mathrm{mg} / \mathrm{L} / 2 \mathrm{mg} / \mathrm{L}, 0.5 \mathrm{mg} / \mathrm{L} / 2 \mathrm{mg} / \mathrm{L}, 1 \mathrm{mg} / \mathrm{L} / 2$ $\mathrm{mg} / \mathrm{L}, 2 \mathrm{mg} / \mathrm{L} / 2 \mathrm{mg} / \mathrm{L}, 4 \mathrm{mg} / \mathrm{L} / 2 \mathrm{mg} / \mathrm{L}, \mathrm{NaOCl} / \mathrm{H}_{2} \mathrm{O}_{2}$ and $0.05 \mathrm{mg} / \mathrm{L}, 0.1 \mathrm{mg} / \mathrm{L}, 0.5 \mathrm{mg} / \mathrm{L}, 1 \mathrm{mg} / \mathrm{L}, 2 \mathrm{mg} / \mathrm{L}, 4 \mathrm{mg} / \mathrm{L}, \mathrm{NaOCl}$.
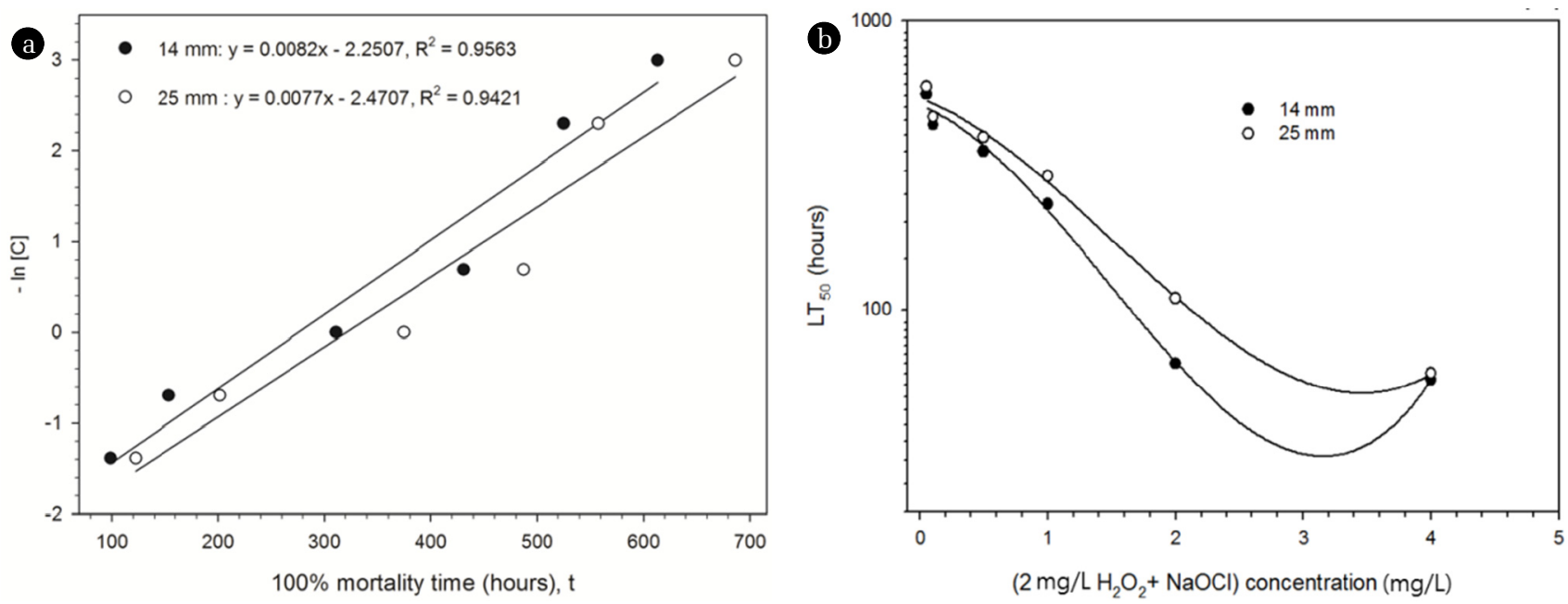

Fig. 7. Plot of $-\mathrm{In}[\mathrm{C}]$ versus $100 \%$ mortality time (a) and time required for $50 \%$ mussel mortality at different mixed oxidant concentrations (b). Graph plotted at best fitted route.

greater biocide resistance such as sex and season cannot be discounted [45, 49].

\section{Conclusions}

To evaluate the efficient use of hydrogen peroxide along with hypochlorite, two life phases (larva and mussel) of blue mussels were treated. For field application extensive study is required. In order to reduce the toxicity of the chlorine compound, which is being banned in some countries, the dose minimization approach was introduced throughout the experiments. The notable findings and analysis of them are:

1) M. edulis veliger larvae showed tolerance to $0.05 \mathrm{mg} / \mathrm{L}$ free residual chlorine but not to $0.5 \mathrm{mg} / \mathrm{L}$ of hydrogen peroxide.

2) Larvae mortality increased with increase in free residual chlorine concentration, and it was found to be synergic when the peroxide was used in parallel. The synergic effect of peroxide addition was 9 folds at $0.1 \mathrm{mg} / \mathrm{L}$ free residual chlorine dose.

3) Bigger sized mussels showed more tolerant to all peroxide/chlorine treatments than the smaller group. The average gap between two groups was $45 \mathrm{~h}$ duration in mortality time. The rate of reaching $100 \%$ mortality was $0.9-1.0 / \mathrm{h}$ for $25 \mathrm{~mm}$ group whereas that was $0.7-0.8 / \mathrm{h}$ for $14 \mathrm{~mm}$ group.

4) Hydrogen peroxide applied in $2 \mathrm{mg} / \mathrm{L}$ concentration with chlorine served to effectively reduce the time reaching higher 
mussel mortality.

5) Enhancement of larvae mortality (up to 19 folds) and reduction in lethal time (up to $22 \%$ ) of mussel could be benefited for raw water users by averting micro- and macro-fouling as well as maintaining the endorsed environmental safety by reducing the production of harmful chlorine by-products.

\section{Acknowledgments}

This research was a part of the project entitled as 'Improvement Technologies of Hypoxic Water Mass in Semi-Enclosed Coastal Bay', funded by the Ministry of Oceans and Fisheries, and BK21 plus program, South Korea.

\section{References}

1. Murthy PS, Veeramani P, Ershath MIM, Venugopalan VP. Biofouling evaluation in the seawater cooling circuit of an operating coastal power plant. Power Plant Chem. 2011;13: 314-319.

2 Rao TS, Kora AJ, Chandramohan P, Panigrahi BS, Narasimhan SV. Biofouling and microbial corrosion problem in the thermo-fluid heat exchanger and cooling water system of a nuclear test reactor. Biofouling 2009;25:581-591.

3. Sahu G, Achary MS, Satpathy KK, Mohanty AK, Biswas S, Prasad MVR. Studies on the settlement and succession of macrofouling organisms in the Kalpakkam coastal waters, southeast coast of India. Indian J. Geo-Mar. Sci. 2011;40:747-761.

4. Kovalak WP, Longton GD, Smithee RD. Zebra mussels: Biology, impacts, and control. In: Nalepa TF, Schloesser DW, eds. Boca Raton, Florida: Lewis Publishers; 1993. p. 359-380.

5. Cloete TE, Jacobs L, Brozel VS. The chemical control of biofouling in industrial water systems. Biodegradation 1998;9:23-37.

6. Rajagopal S, Van der Velde G. Operational and environmental consequences of large industrial cooling water systems. In: Rajagopal S, Jenner HA, Venugopalan VP eds. New York: Springer; 2012. p. 127-162.

7. Jenner HA, Janssen-Mommen JPM. Monitoring and control of Dreissena polymorpha and other macrofouling bivalves in the Netherlands. In: Nalepa TF, Schloesser DW, eds. Boca Raton, Florida: Lewis Publishers; 1993. p. 537-554.

8. Bott TR. Biofouling control in cooling water. Int. J. Chem. Eng. 2009;2009:619873.

9. Rajamohan R, Vinitha E, Venugopal VP, Narasimhan SV. Chlorination byproducts and their discharge from the cooling water system of a coastal electric plant. Curr. Sci. 2007;93:1608-1612.

10. Allonier AS, Khalanski M, Camel V, Bermond A. Characterization of chlorination by-products in cooling effluents of coastal nuclear power stations. Mar. Poll. Bull. 1999;7:1232-1241.

11. Almeida JR, Vasconcelos V. Natural antifouling compounds: Effectiveness in preventing invertebrate settlement and adhesion. Biotechnol. Adv. 2015;33:343-357.

12. Wong YH, Wang H, Ravasi T, Qian PY. Involvement of Wnt signaling pathways in the metamorphosis of the bryozoan Bugula neritina. PLoS One 2012;7:e33323.

13. Coyne KJ, Qin XX, Waite JH. Extensible collagen in mussel byssus: A natural block copolymer. Science 1997;277: 1830-1832.

14. Coyne KJ, Waite JH. In search of molecular dovetails in mussel byssus: From the threads to the stem. J. Exp. Biol. 2000;203: 1425-1431.

15. Papov VV, Diamond TV, Biemann K, Waite JH. Hydroxyargininecontaining polyphenolic proteins in the adhesive plaques of the marine mussel Mytilus edulis. J. Biol. Chem. 1995;270: 2018392.

16. Waite JH, Qin XX. Polyphosphoprotein from the adhesive pads of Mytilus edulis. Biochemistry 2001;40:2887-2893.

17. Gantayet A, Ohana L, Sone ED. Byssal proteins of the freshwater zebra mussel, Dreissena polymorpha. Biofouling 2013;29:77-85.

18. Verweer A, Vinex M, Degrear S. The effect of temperature and salinity on the survival of Mytilopsis leucophaeata larvae (Mollusca, Bivalvia): The search for environmental limits. J. Exp. Mar. Biol. Ecol. 2007;348:111-120.

19. Santos LH, Araújo AN, Fachini A, Pena A, Delerue-Matos C, Montenegro MC. Ecotoxicological aspects related to the presence of pharmaceuticals in the aquatic environment. J. Hazard. Mater. 2010;175:45-95.

20. Cleuvers M. Aquatic ecotoxicity of pharmaceuticals including the assessment of combination effects. Toxicol. Lett. 2003;142: 185-194.

21. Flaherty CM, Dodson SI. Effects of pharmaceuticals on Daphnia survival, growth, and reproduction. Chemosphere 2005;61:200-207.

22. Nalepa TF, Schloesser DW. Zebra mussels: Biology, impacts and control. Boca Raton, Florida: Lewis Publishers; 1992. p. 621-641.

23. Rajagopal S, Nair KVK, Van der Velde G, Jenner HA. Response of mussel Brachidontes striatulus to chlorination: An experimental study. Aquat. Toxicol. 1997;39:135-149.

24. White GC. Handbook of chlorination and alternative disinfectants. New York: Wiley; 1999.

25. Masilamonia G, Jesudoss KS, Nandakumar K, Satapathy KK, Azariah J, Nair KVK. Lethal and sub-lethal effects of chlorination on green mussel Perna viridis in the context of biofouling control in a power plant cooling water system. Mar. Environ. Res. 2002;53:65-76.

26. Van Benschoten JE, Jensen JN, Harrington DK, DeGirolamo D. Zebra mussel mortality with chlorine. J. Am. water works Ass. 1995;5:101-108.

27. Zar JH. Bio-statistical Analysis. Englewood Cliffs, New Jersey: Prentice-Hall; 1984. p. 718.

28. Chen L, Li X, Zhang J, et al. Production of hydroxyl radical via the activation of hydrogen peroxide by hydroxylamine. Environ. Sci. Technol. 2015;49:10373-10379.

29. Tomat R, Rigo A, Salmaso R. Kinetic study on the reaction between $\mathrm{O}_{2}$ and hydroxylamine. J. Electroanal. Chem. Interfacial Electrochem. 1975;59:255-260.

30. Storz G, Tartaglia LA, Farr SB, Ames BN. Bacterial defenses' against oxidative stress. Trends Genet 1990;6:363-368.

31. Mouabad AMA, Fdil A, Maarouf A, Pihan JC. Pumping behavior and filtration rate of the freshwater mussel Potomida littoralis 
as a tool for rapid detection of water contamination. Aqua Ecol. 2001;35:51-60.

32. Muller F. The nature and mechanism of superoxide production by the electro transport chain; its relevance to aging. J. Am. Aging Ass. 2000;23:227-253.

33. McCord JM, Fridovich I. Superoxide dismutase: An enzymatic function for erythrocuprein (hemocuprein). J. Biol. Chem. 1969;244:6049-6055.

34. Cerenius L, Soderhall K. Variable immune molecules in invertebrates. J. Exp. Biol. 2013;216:4313-4319.

35. Thompson IS, Richardson CA. The response of the common cockle, Cerastoderma edule, to simulated chlorination procedures. Biofouling 1993;7:299-312.

36. Cleuvers M. Initial risk assessment for three $\beta$-blockers found in the aquatic environment. Chemosphere 2005;59:199-205.

37. Backhaus T, Faust M. Predictive environmental risk assessment of chemical mixtures: A conceptual framework. Environ. Sci. Technol. 2012;46:2564-2573.

38. Berlett BS, Stadtman ER. Protein oxidation in aging, disease, and oxidative stress. J. Biol. Chem. 1997;272:20313-20316.

39. Tremolada P, Finizio A, Villa S, Gaggi C, Vighi M. Quantitative inter-specific chemical activity relationships of pesticides in the aquatic environment. Aquat. Toxicol. 2004;67:87-103.

40. Cronin MTD, Dearden JC. QSAR in toxicology. 2. Prediction of acute mammalian toxicity and interspecies correlations. Mol. Inform. 1995;14:117-120.

41. Zhang XJ, Qin HW, Su LM, et al. Interspecies correlations of toxicity to eight aquatic organisms: Theoretical considerations. Sci. Total Environ. 2010;408:4549-4555.
42. Rajagopal S, Van der Velde G, Van der Gaag M, Jenner HA. How effective is intermittent chlorination to control adult mussel fouling in cooling water systems? Water Res. 2003;37: 329-338.

43. Kirkwood TB, Austad SN. Why do we age? Nature 2000;408: 233-238.

44. Buettemer W, Abele D, Costantini D. From bivalves to birds: Oxidative stress and longevity. Funct. Ecol. 2010;24:971-983.

45. Jenner HA. Chlorine minimization in macrofouling control in The Netherlands. In: Jolly RL, Bull RJ, Davies WP, Katz S, Roberts MH, Jacobs VA, eds. Water chlorination: Chemistry, environmental impact and health effects. Vol. 5. Michigan Lewis Publishers; 1985. p. 1425-1433.

46. Jones HD, Richards OG, Southern TA. Gill dimensions, water pumping rate and body size in the mussel Mytilus eduulis L. J. Exp. Mar. Biol. Ecol. 1992;155:213-237.

47. Enrique GO, Julian B, Elena N, Miriam H, Lewis LV, Luis G. Individual and mixture effects of selected pharmaceuticals on larval development of the estuarine shrimp Palaemon longirostris. Sci. Total Environ. 2016;540:260-266.

48. Opresko DM. Review of open literature on effects of chlorine on aquatic organisms. Report No. EPRI EA-1491. Palo Alto, CA: Electric Power Research Institute; 1980. p. 1-29.

49. Martin ID, Mackie GL, Baker MA. Control of the biofouling mollusk, Dreissena polymorpha (Bivalvia: Dreissenidae), with sodium hypochlorite and with polyquaternary ammonia and benzothiazole compounds. Arch. Environ. Contam. Toxicol. 1993;24:381-388. 